\title{
PROFESIONALNE PREVARE KAO PRETNJA FUNKCIONISANJU PRIVREDNIH DRUŠTAVA
}

\author{
Nada Arežina, \\ Vule Mizdraković, \\ Goranka Knežević
}

Univerzitet Singidunum, Beograd, Srbija

\begin{abstract}
Apstrakt:
Cilj ovog rada je da ukaže na rizik od profesionalnih prevara sa kojim se organizacije širom sveta sve više suočavaju. Profesionalne prevare, odnosno prevare počinjene od strane zaposlenih i uprave, ne samo da ugrožavaju poslovanje jednog privrednog društva po pitanju njenog finansijskog statusa, već u značajnoj meri utiču na njen ugled. Različita istraživanja pokazuju da oko $5 \%$ godišnje dobiti privredna društva gube usled neke od različitih vidova prevara, a pod uticajem globalizacije, brzog tehnološkog razvoja i rasta tržišta logično je očekivati da će ovaj iznos rasti u budućnosti. Ipak, kako bi se rizici od kriminalnih radnji uočili na vreme, potrebno je prepoznavanje simptoma kriminalnih radnji kako bi se iste mogle blagovremeno sprečiti. Različita istraživanja u ovom smislu ukazivala su na glavna upozorenja i crvene zastavice koje bi mogle poslužiti u svrsi njihovog blagovremenog otklanjanja i uspostavljanja adekvatnih internih kontrola koje će na efikasan način umanjiti rizik od njihovog postojanja. U ovom radu ćemo se osvrnuti upravo na prethodno pomenute aspekte.
\end{abstract}

Ključne reči:

kriminalne radnje, crvene zastavice, interne kontrole, rizik.

\section{UVOD}

Kriminalne radnje i prevare predstavljaju rizik sa kojim se suočavaju sve vrste privrednih društava, nezavisno od njihove veličine, delatnosti ili države u kojoj se nalaze. U godišnjem izveštaju revizorske kuće PricewaterhouseCoopers, u daljem tekstu PWC, u kome je učestvovalo preko 6.000 ispitanika iz 115 različitih država širom sveta, istraživanja pokazuju da privredni kriminal u 2016. godini, beleži blagi pad od 1\%. Ipak, ovo ne treba shvatiti suviše rigidno. Naime, autori navode da pomenuto može biti posledica poražavajuće činjenice, a to je da se privredni kriminal razvija prebrzo te da tradicionalne kontrole uprave nisu adekvatne da prate tempo promena. Šta više, troškovi počinjenih prevara pojedinačno su u porastu. Dalje, evidentan je pad u detekciji kriminalnih aktivnosti, metodama kao što su kontrole uprave i to za 7\%, ali i činjenica da jedna od pet organizacija nije sprovela nijedan metod procene kriminalne radnje u poslednjih 24 meseca, kao i da je najveći procenat kriminalnih radnji slučajno detektovan.

Poslednje ACFE istraživanje pokazuje da je najviše kriminalnih radnji u organizacijama otkriveno putem dojava, koje su imale bolji učinak od interne revizije i kontrole uprave, dok je eksterna revizija usled ograničenosti svojih mehanizama tek na osmom mestu otkrivanja kriminalnih aktivnosti u organizaciji (ACFE, 2016). Istraživanje revizorske kuće KPMG, koje je uključilo ispitivanje forenzičkih ispitivača prevara o detaljima počinilaca kriminalnih radnji u organizacijama širom sveta, u periodu između 2013. i 2015. godine, takođe pokazuje da su dojave i žalbe imale bolji učinak od kontrola uprave, dok su uzbunjivači, kao i slučajno otkrivene kriminalne radnje imale bolji učinak od interne revizije (KPMG, 2016). U izveštaju se navodi podatak o metodama detekcije u zavisnosti od toga da li počinioci kriminalnih radnji nastupaju samostalno ili u dosluhu. Za počinioce koji nastupaju samostalno, glavni metod otkrivanja su kontrole uprave, slučajni metod ili interna revizija, dok kod počinioca koji rade u dosluhu glavne metode jesu uzbunjivači, kontrole uprave kao i dojave. Takođe, uzbunjivači i 
dojave predstavljaju do sada najveću uspešnost u otkrivanju grupa od pet i više počinilaca kriminalnih radnji, što ukazuje da druge metode postaju neefikasne u detektovanju većih grupa počinilaca koje rade u dosluhu. Štaviše, značajnije štete prouzrokuju prevaranti koji rade u dosluhu, jer je za njihovo otkrivanje potreban duži vremenski period. Stoga je neophodan sveobuhvatan pristup razumevanja rizika od kriminalnih radnji, kao prelazak sa pasivnog i tradicionalnog pristupa kontroli na proaktivnije i savremenije metode, ali i razumevanja osnovnih elemenata i motiva prevarnih postupaka u samoj organizaciji.

\section{ELEMENTI KRIMINALNIH RADNJI}

Prvi koji je proučavao elemente koji omogućavaju da se počini kriminalna radnja jeste Donald Cressey, kriminolog koji je davne 1950. godine u svom radu pisao o motivima i okolnostima koje navode osobe da počine kriminalnu radnju. On je u svom radu intervjuisao 250 počinilaca kriminalnih aktivnosti i ustanovio zajedničke elemente za činjenje kriminalne radnje, poznate kao trougao prevare (Cressey, 1950):

- Pritisak,

- Mogućnost,

- Opravdavajući stavovi ili racionalizacija.
Mogućnost da se počini kriminalna aktivnost predstavlja važan činilac prevarnog trougla. Verovatnoća ove kategorije se povećava, kada počinilac uoči način da iskoristi svoju trenutnu poziciju i kredibilitet koji ima u organizaciji, kako bi rešio svoje finansijske probleme, uz saznanje da neće biti uhvaćeni u prevari. Samim tim, slab sistem interne kontrole kao i nesposobnost da se izvrši ocena obavljenog posla, nemogućnost pristupa informacijama, nemogućnost da se počinilac kazni, apatičnost, ali i nedostatak traga revizije, upravo će povećati mogućnost da se počini kriminalna radnja.

Racionalizacija podrazumeva pravdanje postupaka počinioca i često se odnosi na osobe koje smatraju da su poštene i da su uhvaćene u lošoj situaciji i okolnostima. Neka od opravdanja za nezakonite postupke počinioci mogu iskazati na sledeće načine:

- „kompanija mi duguje novac“

- „novac pozajmljujem i vratiću ga“

- „zaslužujem više“ itd.

Na taj način, počinioci pokušavaju da „operu“, odnosno opravdaju svoju neminovnost postupka na način koji bi bio prihvatljiv u društvu.

Različiti autori su vremenom modifikovali i usložnjavali pomenuti trougao, ali i različito definisali pomenute kategorije. Lister smatra da motiv ili pritisak predstavlja „izvor toplote za požar" i navodi sledeće komponente: lični pritisak, kako bi se obezbedio željeni način života; finansijski interes menadžera; ali i eksterni pritisak usmeren na poslovne finansijske stabilnosti kao i očekivanja investitora i tržišta. Takođe, Lister smara da je prilika ,gorivo koje pokreće" i navodi da ukoliko postoji motiv za počinjenom kriminalnom radnjom, ista se ne može počiniti bez prilike za njeno izvršenje. Neki od primera koje navodi pomenuti autor jesu veliki obrt, odnosno smena menadžmenta, nedostatak segregacije dužnosti

Kada je reč o pritiscima, oni mogu uključiti finansijske pritiske, poroke, pritiske na radnom mestu i druge vrste pritisaka. Primeri finansijskih pritisaka mogu uključivati pohlepu, život iznad finansijskih mogućnosti ili standarda, dugove, slabu kreditnu sposobnost, lične finansijske gubitke, postojanje neočekivanih finansijskih potreba. Poroci se mogu odnositi na zavisnost pojedinaca prema kockanju, opijatima, alkoholu i drugim adiktivnim sredstvima koja predstavljaju najteži oblik pritisaka (Petković, 2010). Pritisci ili motivi na radnom mestu mogu biti: nezadovoljstvo radnim mestom i okruženjem, strah od gubitka posla ili osećaj pojedinaca da nije dovoljno plaćen za taj posao, ali i želja pojedinca da prevari sistem. Kada je reč o finansijskom pritisku, Cressey navodi da osobe postaju počinioci onda kada vide sebe u određenim finansijskim problemima i obavezama za činjenje radnji koje se smatraju kažnjivim, i koje će shodno tome biti sprovedene tajnim načinima i metodama (Cressey, 1950). kao i kompleksna struktura i transakcije u organizaciji. Treću komponentu, racionalizaciju, Lister definiše kao „vazduh koji omogućava vatri da gori“. Iako autor smatra da revizori ne mogu proceniti individualne karakteristike pojedinaca, napominje da bi revizori trebalo da budu sposobni da ocene korporativnu kulturu organizacije koju kontrolišu (Lister, 2007).

Pojedini autori smatraju da pozicija zaposlenog u organizaciji omogućava da se počini prevara. Takođe, postoji pozitivna korelacija između prilike i mogućnosti da se počini ista, kao i sposobnosti da se ona prikrije (Vona, 2008). Stoga, razumevanje mogućnosti da se počini kriminalna radnja, omogućava identifikaciju šeme kriminalnih radnji. Davne 1984. godine, Albrecht i saradnici su predložili alternativu za trougao prevare, koju čini lični integritet umesto racionalizacije, koji je posebno primenljiv na lažno finansijsko izveštavanje gde su vidljivi pritisci različite vrste (procene analitičara, istorija prodaje, rast zarade itd). Oni su integritet definisali kao lične 


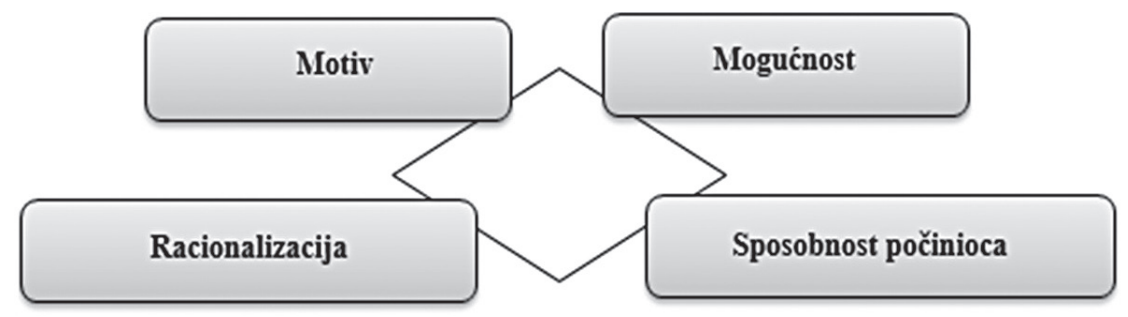

Slika 2. Dijamant prevare (Fraud diamond)

Izvor: Wolfe \& Hemarson (2004)

propise etičkog ponašanja koje osoba usvaja. Autori navode da motivi mogu biti finansijski i nefinansijski. Kao finansijske motive navode lične finansijske probleme, pad prodaje, nemogućnost izlaženja na kraj sa konkurencijom, život iznad svojih mogućnosti, lične dugove, neočekivane finansijske potrebe i nemogućnost ispunjena očekivanja. Sa druge strane, nefinansijski problemi mogu uključivati frustracije na poslu, pa čak i izazov da se pobedi sistem (Albrecht et al. 2008). Dalje, pojedini autori pored finansijskih i nefinansijskih, navode političke i društvene pritiske, u smislu da pojedinci ne mogu podneti propast usled stečene reputacije (Murdock, 2008). Međutim, u smislu proširenja postojećeg trougla prevare, Wolfe i Hemarson su 2004. godine predstavili dijamant prevare i dodali četvrti uslov, a to je sposobnost počinioca.

Takođe, autori smatraju da postoji nekoliko osnovnih opasnosti da se počini prevara, a to su autoritativna pozicija u organizaciji, sposobnost razumevanja računovodstvenog sistema i njegovog funkcionisanja kao i slabosti internih kontrola, postojanje samopouzdanja da počinilac neće lako biti otkriven, ali i sposobnost suočavanja sa stresom kada se učini loše delo. Takođe, pojedini autori upućuju da motiv može biti proširen tzv. MICE model koji predstavlja akronim za novac, ideologiju, prinudu i ego (Money, Ideology, Coercion and Ego). Prethodno pomenute naznake, u smislu proširenja trougla prevara, autori Kassem i Higson su integrisali u jedan model koji uključuje motivaciju, priliku, integritet, i sposobnosti, koji su nazvali Novi model trougla prevare (Kassem \& Higson, 2012)

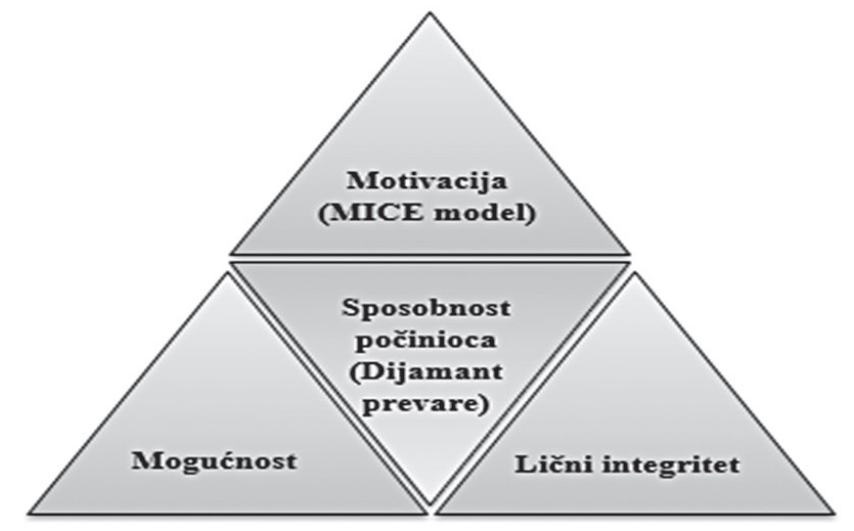

Slika 3. Novi model trougla prevare

Izvor: Kassem \& Higson (2012)
Ideološki motivatori opravdavaju sredstva koja omogućavaju krađu novca ili učestvovanje u prevarama, kako bi bili percipirani sa većim uvažavanjem u skladu sa svojim uverenjima (ideologija). Prinuda nastaje kada su pojedinci nevoljno povučeni u šeme prevare, ali se brzo mogu preobratiti u uzbunjivače. Ego može da bude motiv za prevaru, iz razloga što osobe ne vole da gube ugled ili poziciju moći pred društvom ili porodicom. Ovaj vid društvenog pritiska često predstavlja motiv da se počini prevara, kako bi se zadržao postojeći ugled i zadovoljio sopstveni ego. Ipak, detektovanje prevara nije lak zadatak i zahteva temeljan pristup i znanje o prirodi prevare kao i kako se ista može počiniti i sakriti. Stoga je potrebno sagledati sve prethodno pomenute modele, kako bi se stvorila potpunija slika o razlozima zbog kojih se čini prevara.

\section{PONAŠANJA POČINILACA PROFESIONALNIH PREVARA I NJIHOVE KARAKTERISTIKE}

Organizacije često znaju biti veoma iznenađene kada otkriju da je zaposleni počinio prevaru, posebno ukoliko je već duže vremena zaposlen, jer su neretko nepripremljene i imaju slabe interne kontrole usmerene na odvraćanje od prevara. Takođe, često se zaboravlja da se pojedinci koji vrše prevaru najčešće ne ponašaju neprikladno i loše, jer žele da odaju utisak poštene osobe. Iz tih razloga, i brojnih drugih, za važno je da organizacija poseduje interne kontrole koje sprečavaju mogućnost za prevaru i smanjuju uzročne faktore kako bi umanjile rizik od prevare.

Istraživanje koje je 2016. godine sproveo ACFE navodi sledeće crvene zastavice ponašanja počinilaca kriminalnih radnji u organizaciji.

Najčešći motivi počinilaca prevarnih radnji su: život iznad svojih mogućnosti, finansijske poteškoće, prevelika bliskost sa kupcem ili klijentom, odbijanje da se dele dužnosti, i porodični problemi. Takođe, istraživanje je pokazalo da su u 92\% slučaja počinioci pokazali jednu od navedenih karakteristika, dok su u 57\% slučajeva počinioci pokazali kombinaciju više predočenih ponašanja. Istraživanje KPMG-a koje je obuhvatilo 750 počinilaca kriminalnih radnji u periodu od 2013. do 2015. godine, ukazuje na sledeće motive činjenja prevara.

Istraživanje PWC-a ukazuje da su najčešći počinioci kriminalne radnje univerzitetski obrazovani muškarci starosti od 31 do 40 godina, koji su zaposleni u organizaciji 3 do 5 godina. Podrazumeva se da je potrebno da počinilac provede određeni period na radnom mestu, da bi razumeo kako sistem funkcioniše i samim tim ustanovio njegove slabe tačke (PWC, 2016). Kada je reč o polu, potrebno je posmatrati kriminalne radnje sa šireg aspekta. U tom smislu, ACFE istraži- 


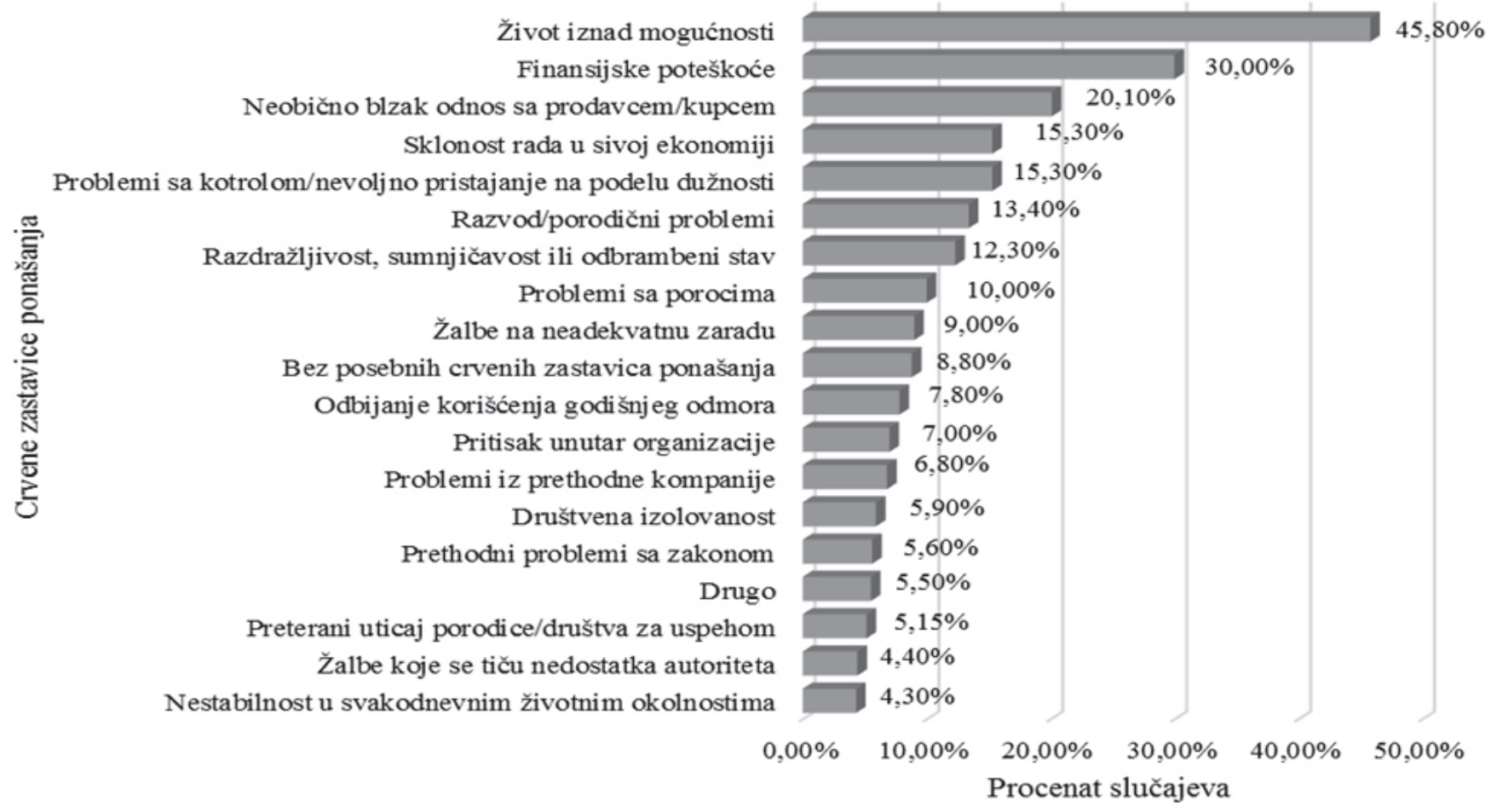

Izvor: ACFE (2016)

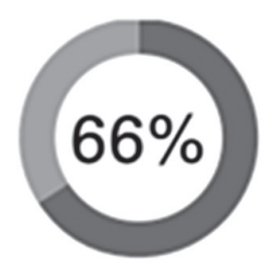

Lična finansijska korist

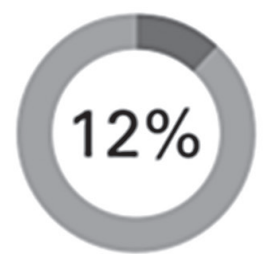

Żelja da se ispuni planirani budžet/da se salriju gubici kako bi se zadržala pozicija na poslu

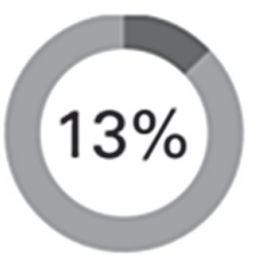

Organizaciona kultura

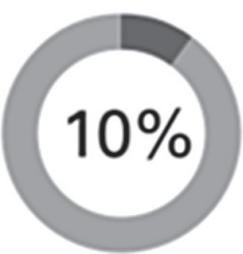

Ostalo, ni jedno od prethodno nabrojanih

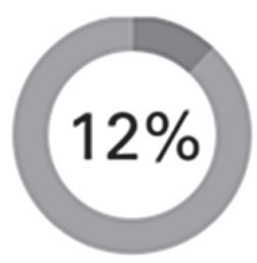

Żelja da se ispune očekivanja da se sakriju gubici

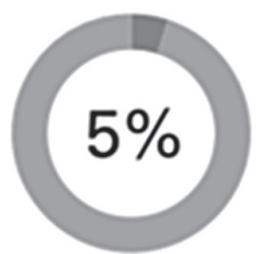

Ostali motivi (manje od 5\%) uključuju: gubitak samopouzdanja, izbegavanje usaglašavanja sa regulativom, fokus na rejtingu $i$ imidžu kompanije, poteškoće u poslovanju

Slika 4. Motivi počinjenih kriminalnih radnji u organizacijama Izvor: KPMG (2016)

vanje navodi različite crvene zastavice, u zavisnosti od pola, gde kod žena preovlađuju finansijske poteškoće, porodični problemi i nekorišćenje godišnjih odmora, dok se sa druge strane kod muškaraca navode bliski odnosi sa kupcima i klijentima i sklonosti ka poslovima u zoni sive ekonomije.

\section{ZAKLJUČNA RAZMATRANJA}

Istraživanja različitih organizacija ukazuju da je za razumevanje i procenu rizika od kriminalne radnje, potrebno razmotriti sve modele prevare i ponašanja zaposlenih $u$ 
brzom i rizičnom poslovnom okruženju, kako bi se bolje razumeli faktori koji mogu ukazati na postojanje kriminalnih aktivnosti u organizaciji. Stoga je neophodno usmeriti se na sprovođenje sofisticiranijih i efikasnijih mera, kako bi se redukovao rizik od pojave kriminalnih radnji, ali i podigla svest o pretnjama koje ugrožavaju poslovanje. Proaktivni pristupi mogu uključiti forenzičku analizu podataka koja može poslužiti kao moćna alatka za sprečavanje, otkrivanje $\mathrm{i}$ istraživanje prevare, korupcije, ali i drugih vrsta prevarnih radnji u organizacijama. Na primer, istraživanja koja je sproveo ACFE pokazuju da organizacije koje koriste proaktivne analitičke tehnike, uključujući forenzičke analize podataka, imaju za 60\% manju medijanu gubitka od kriminalnih radnji u odnosu na organizacije koje ne koriste ovakvu vrstu tehnologije. Osim toga, forenzička analiza podataka jeste ključna komponenta efikasnog upravljanja rizikom prevara kao što je opisano u najnovijem vodiču za prevare organizacije COSO, objavljenom 2016. godine, posebno oko oblasti procene prevara rizika, njihove prevencije i otkrivanja. Integrisanjem i uvođenjem forenzičkih analiza podataka u postupke revizije i usklađivanjem programa za nadgledanje, organizacije mogu poboljšati procenu rizika, otkriti potencijalne zloupotrebe na vreme i poboljšati planiranje revizije ili istrage rada na terenu.

\section{LITERATURA}

ACFE. (2016). Report to the Nations on Occupational Fraud and Abuse. Preuzeto 10. maja 2016. sa https://s3-us-west-2.amazonaws.com/acfepublic/2016-report-to-the-nations.pdf

Albrecht, W.S., Albrecht, C., \& Albrecht, C.C. (2008). Current trends in fraud and its detection. Information Security Journal: A global perspective, 17(1), 1-32. doi:10.1080/19393550801934331

Cressey, D. (1950). The criminal violation of financial trust. American Sociological Review, 15(6), 738-743.

Kassem, R., \& Higson, A. (2012). The New Fraud Triangle Model. Journal of Emerging Trends in Economics and Management Sciences, 3(3), 191-195.

KPMG. (2016). Global profiles of the fraudster:Technology enables and weak controls fuel the fraud. KPMG International. Preuzeto 01. juna 2016. sa https://assets.kpmg.com/content/dam/kpmg/pdf/2016/05/profiles-of-the-fraudster.pdf

Lister, M. (2007). A practical approach to fraud risk. Internal Auditor, 64(6), 61-65.

Murdock, H. (2008). The three dimensions of fraud. Internal $\mathrm{Au}$ ditor, 65(4), 1-14.

Petković, A. (2010). Forenzička revizija. Novi Sad: Proleter.

PWC. (2016). Adjusting The Lens on Economic Crime. Preuzeto 10. maja 2016. sa http://www.pwc.com/gx/en/economiccrime-survey/pdf/GlobalEconomicCrimeSurvey2016.pdf

Vona, L.W. (2008). Fraud risk assessment: Building a fraud audit program. New Jersey: Wiley and Sons.

Wolfe, D.T., \& Hermanson, D.R. (2004). The Fraud diamond: Considering the four elements of fraud. The CPA Journal, pp. 38-42.

\section{OCCUPATIONAL FRAUD AS A THREAT TO THE BUSINESS OPERATIONS}

\section{Abstract:}

The aim of this paper is to point out the risk of occupational fraud that organizations around the world are faced with. Professional fraud, or fraud committed by employees and management, not only endanger the operations of a company in terms of its financial status, but significantly affect its reputation. Various studies show that approximately $5 \%$ of annual profit companies lost due to some of the different types of occupational fraud. Under the influence of globalization, rapid technological development and growth of the market it is logical to expect that previously mentioned issue will have an increasing trend in the future. However, in order to detect fraud in a timely manner, it is necessary to identify their symptoms. Various studies, in this regard, are trying to point out the warnings and red flags that could help in their elimination and the establishment of adequate internal controls that will effectively reduce the risk of their existence. In this paper, we will focus on previously mentioned issues.

Keywords:
fraud,
red flags,
internal controls,
risk.

